$$
\begin{aligned}
& \text { قســم: الجراحسة والولادة . }
\end{aligned}
$$

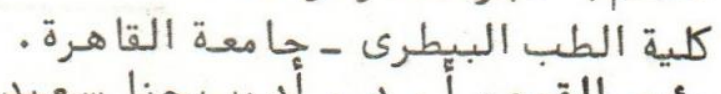

$$
\begin{aligned}
& \text { رئيس القسم : أ . د د . أد يب حنا سعيد الطرة . }
\end{aligned}
$$

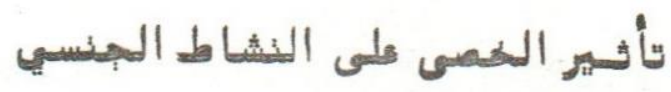

$$
\begin{aligned}
& \text { في }
\end{aligned}
$$

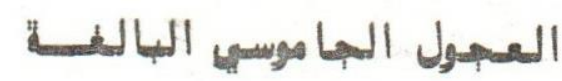

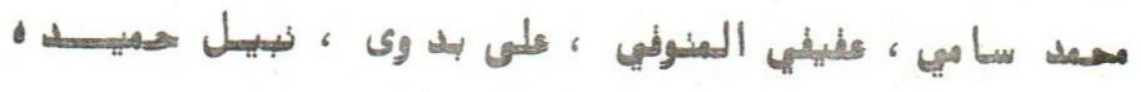

$$
\begin{aligned}
& \text { أجريت هـذه الد زاسة على ثلاث من الطلائق الجاموسي التي }
\end{aligned}
$$

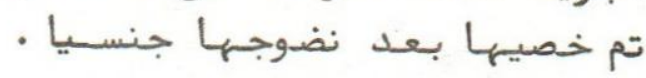

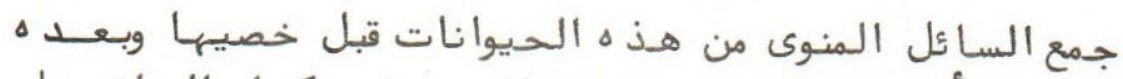

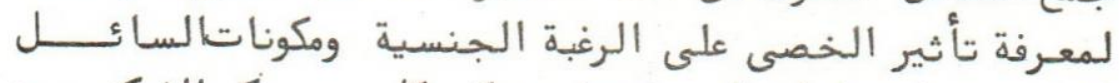

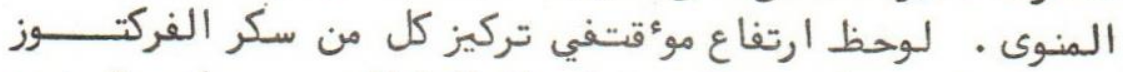

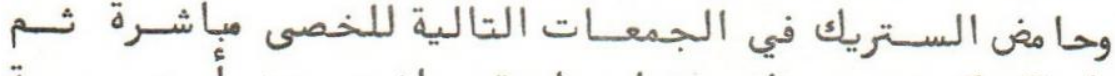

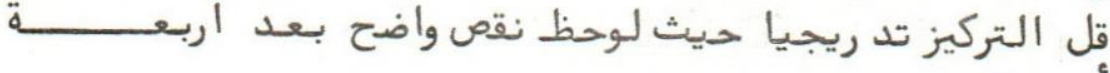

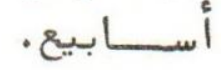

تناقص عدد الحيامن حيث اختفى تماما بعد ثلاثـة أسابيــع

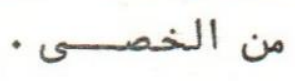

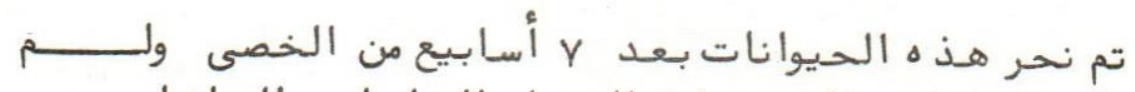

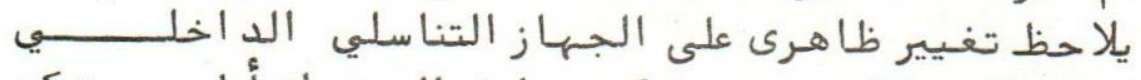

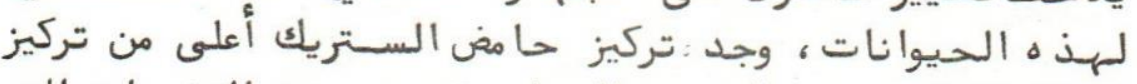

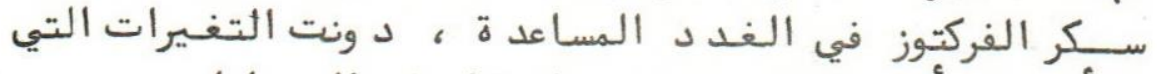
طرأت على أنسجة الغدي الفد د المختلفة لهـذه هـ الحيوانات. 

Dept. of Surg. Obstet. Gyn. and A.I., Faculty of Vet. Med., Cairo University, Head of Dept. Prof. Dr. A.H. Saeid.

\title{
EFFECT OF CASTRATION ON THE REPRODUCTIVE ACTIVITY OF ADULT BUFFALO BULLS
}

(With 2 Tables \& 4 Figs.)

\author{
By \\ M.S.S. ABDOU; A.A. EL-MENOUFY; A.B.A. BADAWY \\ and N.A. HEMEIDA \\ (Received at 11/5/1982)
}

\begin{abstract}
SUMMARY
Three adult sexually rested buffalo bulls were castrated at 4 years of age. Four to five weeks after castration the bulls exhibited diminished libido and failed to respond to a female teaser, indicating the great dependence of the adult buffalo on gonadal hormones. On the third week post-castration, ejaculates collected from these bulls were completely devoid of spermatozoa. The first post-castrational ejaculates showed twofold increase in their fructose and citric acid concentrations which is thought to be due to a transient effect, on the accessory glands, of androgenic steroids from the adrenals. Four weeks after castration citric acid was about $64 \%$ while fructose was $20 \%$ of the precastrate levels.

At slaughter, 7 weeks after castration the gross morphology of the accessory glands was normal and there was more citric acid than fructose in the vesicular glands and ampullae. The histological picture of accessory organs 7 weeks after castration was described.
\end{abstract}

\section{INTRODUCTION}

It is well known that the growth rate, ultimate size, histological appearance and secretory output of the accessory reproductive organs are subject to intricate control by a variety of factors among which the male sex hormone plays, by far, the most important and decisive role (MANN and PARSONS, 1950; LINDNER and MANN, 1960 and MANN, 1964). Castration, was reported to bring about morpho-histological regressive changes in the accessory glands associated with decline in their content of fructose (MANN, DAVIES and HUMPHREY, 1949; MANN and PARSONS, 1950 and GASSNER, HILL and SULZBERGER, 1952), and citric acid (HUMPHREY and MANN 1949).

In a recent study on buffalo steers, EISSA (1980) observed that the decline in fructose concentration in the vesicular glands, ampullae and internal prostate was much more conspicuous than the decline in the concentration of citric acid in the same glands. These data suggested differences between the various accessory glands in their relative dependence on testicular androgens.

The aim of the present work is to report on early effects of castrating adult buffalo bulls on libido and ejaculate characteristics, with emphasis on fructose and citric acid levels, as well as on the morpho-histological changes of the reproductive accessory glands.

Assiut Vet. Med. I. Vol. 12, No. 23, 1984. 


\section{M.S.S. ABDOU, et al.}

\section{MATERIAL and METHODS}

Three sexually mature buffalo bulls aged 4 years were used in the present study. These animals were of above average sexual desire and were used in routine semen collection. Sexual rest was given for about a month before the beginning of the experiment.

Before castration, two control semen collections were made using an artificial vagina. Each bull was ejaculated twice on each days of collection. Two (in one bull) to nine (in two bulls) days after the last collection, castration was performed non surgically by crushing the spermatic cord using a Burdizzo forceps. First post-castration collections were obtained after 7 days. Two successive ejaculates were collected weekly from each bull for four weeks. The ejaculates were evaluated for volume, motility and sperm concentration according to the conventional techniques. Fructose and citric acid concentrations in seminal plasma were determined according to the method of MANN, (1948) and SAFFRAN and DENSTEDT (1948), respectively.

The animals were slaughtered 7 weeks after castration and their accessory organs (vesiculer glands, ampullae, internal prostate, and bulbourethral glands) removed, and morphologically examined. Tissue samples were immediately fixed in Bouin's solution and Paraffin sections stained with haematoxyline and eosin were prepared for histological examination. In addition, samples (from the vesicular glands and ampullae) of known weight were diced and homogenized in distilled water using ultra-turax (Janke and kunkel, Ika werk, West Germany) and their fructose (LINDNER and MANN, 1960) and citric acid (SAFFRAN and DENSTEDT, 1948) concentration determined.

\section{RESUL TS}

Until the 4 th week after castration, two successive ejaculates could be collected from each bull weekly. However, in the 5 th week the males exhibited decreased interest in mounting even when a female teaser was used where one ejaculate could hardly be obtained from one bull. In subsequent weeks repeated trials failed to stimulate the desire of the animals.

The ejaculates collected throughout the experimental period did not show marked changes in volume. Meanwhile, the first post-castration ejaculates were necrospermic in 2 bulls, whereas those of the third bull displayed $10-20 \%$ motility.

Table 1 demonstrates the pattern of changes in sperm concentration, seminal plasma fructose and citric acid levels. One week after castration the average sperm concentration of first ejaculates was comparable with the precastrate values. However, the second successive ejaculates showed a marked drop in sperm number. The decrease in sperm concentration was much more clear in the samples collected 2 weeks after castration, whereas ejaculates collected after 3 weeks were completely devoid of spermatozoa.

Unexpectedly the seminal plasma from ejaculates collected a week post-operation showed twofold increase in the concentration of fructose $(819.8 \mathrm{mg} / 100 \mathrm{ml}$ ) and citric acid (696.7 $\mathrm{mg} / 100 \mathrm{ml}$ ) compared to the precastration levels $(478.0$ and $358.8 \mathrm{mg} / 100 \mathrm{ml}$ respectively). A decrease in the concentration of both seminal plasma components ensued two weeks post-castration. Nevertheless, the fructose concentration $(375.9 \mathrm{mg} / 100 \mathrm{ml}$ ) was slightly lower than the precastration level, whereas citric acid concentration remained higher $(432.8 \mathrm{mg} / 100 \mathrm{ml})$ than the control. During the subsequent weeks the seminal plasma concentration of both components declined progressively but the decrease in fructose level was much more marked than that in the level of citric acid. 


\section{CASTRATION \& REPRODUCTIVE ACTIVITY OF BUFFALO}

Table 2 shows the average dimensions, weights and activity of accessory glands of the buffalo bulls 7 weeks after castration. The mean weights recorded for the vesicular glands, ampullae of the vasa deferentia, internal prostate, and bulbo-urethral glands were, 9.2, 3.6, 65.3 and $5.6 \mathrm{~g}$., respectively. The concentration of fructose yn the vesicular glands and ampullae averaged 16.2 and $3.9 \mathrm{mg} / 100 \mathrm{~g}$. In both glands, respectively, the citric acid level was higher averaging 29.7 and $31.6 \mathrm{mg} / 100 \mathrm{~g}$.

On histological examination the vesicular glands showed normal sized alveoli with scanty sectetion. The epithelial lining the alveoli appeared inactive and low with neither bleb-like projections nor basal vacuoles (Fig. 1,2). A decrease in the size of the acini associated with deficency of secretory material and increase in the interstitial tissue was observed in the prostate gland (Fig. 3). The bulbourethral gland showed a decrease in the height of the epithelium and a deficiency of mucoid material. Ampullae were devoid of any spermatozoa and the ampullary glands contained inspissated secretory material (Fig. 4).

\section{DISCUSSION}

A number of studies has indicated that castration of the adult mammal leads to a decrease in the frequency of copulation, although considerable variation exists between species as well as between individuals within a species in regard to how rapidly and to what extent copulatory behaviour decreases after castration. (CLEMENS and CHRISTENSEN, 1975). The present study showed that adult buffalo bulls failed to respond to a female teaser within $4-5$ weeks after castration. On the contrary. Bos taurus bulls have been reported to mount up to one year after castration (FOLMAN and YOLCANI, 1966). To our knowledge, no studies seem to have been done on the plasma testosterone concentration required to elecit normal sexual response in the buffalo. However the present observations would indicate that buffalo males appear to depend greatly upon gonadal hormones for maintaining normal sexual response and even adult trained males cease copulation shortly after castration.

The rapid decline of sperm concentration in ejaculates collected after castration reflects the relatively low number of spermatozoa stored in the vasa deferentia and ampullae. Sperm reserves in the vasa deferentia and ampullae of intact buffalo bulls aged 2.5 years were reported to average $328.5 \times 10(82-850)$ and $2073 \times 10$ (315-6460), respectively (OSMAN, 1972). Much higher reserves in the vasa deferentia $(800-1300 \times 10$ ) and ampullae (3400-6900 X 10 ) were found in beef bulls at an average age of 7.1 years (WEISGOLD and ALMQUIST,
1979).

Since buffalo bulls were firstly ejaculated one week after castration it is not surprising that the collected ejaculates contained nomotile spermatozoa. The high abdominal temperature to which the ampullary spermatozoa had been subjected should be increminated.

One striking observation is the twofold increase in the fructose and citric acid concentrations in the first post-castrational ejaculates. In agreement, EINARSSON (1971) found that following castration of boars, certain seminal plasma components, including fructose, rose in the 2-3 first collected ejaculates and then gradually fell. A prompt post-castrational decrease in the fructose and citric acid in semen and accessory glands was reported for rabbits (MANN and PARSONS, 1950) and bulls (MANN et al. 1949 and GASSNER et al. 1952). In the present study the post-castration rise in seminal plasma fructose and citric acid can presumably be due to a transient hyperstimulation of the accessory glands brought about by increased production of androgenic steroids from the adrenal cortex following the drop in blood level of testicular androgens and the subsequent stimulation of the adenohypophysis to release more trophic

Assiut Vet. Med. 1. Vol. 12, No. 23, 1984. 
hormones. As a matter of fact a large body of evidence points to that gonadectomy in many laboratory animals results in marked development of prostate and seminal vesicles and that such effect could be impaired in castrated adrenalectomised males (PRICE and WILLIAM ASHMAN (1961).

Another noteworthy observation is that 4 weeks after castration the level of citric acid was about $64 \%$ while that of fructose was $20 \%$ of the precastration levels. Moreover, the vesicular ${ }^{-}$glands and ampuliae taken at sloughter 7 weeks after castration contained more citric acid than fructose. In confirmation, EISSA (1980) observed that the level of citric acid in the accessory glands of castrated buffalo bulis was only $45-50 \%$ lower than the levels detected in intact animals. However, the rate of decline in fructose differed between accessory glands being higher in the vesicular glands and ampullae than in the internal prostate. Also in rabbits (HUMPHREY and MANN, 1949) the postcastration fall in citric acid appears to be less prompt that in fructose. It is, thus, probable that seminal fructose and citric acid in the buffalo are produced independently from two different cell types. The low level of androgens left after castration and that produced by the adrenal cortex may be enough to support relatively higher production of citric acid than fructose.

The present results can also imply that the internal prostate and ampullae of the adult male buffalo, shown by EISSA (1980) to differ from vesicular glands in the sense that they contribute more citric acid than fructose are less dependent on circulating androgens. However, the histological regression in all glands noted in this study 7 weeks after castration do not support this possibility.

\section{REFERENCES}

Clemens, L.G. and Christensen, L.W. (1975): Sexual behaviour. In "The Behaviour of Domestic Animals" 3rd Ed. E.S.E. Hafez (Editor) Bailliere Tindall. London.

Einarsson, S. (1971): Studies on the composition of epididymal content and semen in the boar Acta Vet. Scand. Suppl. 36, 1-80.

Eissa, H.M. (1980): Seasonal biological activity of the accessory genital glands of buffalo bulls M.V.Sc. Cairo University.

Folman, Y. and Yolcani, R. (1966): Copulatory behaviour of the prepubertal castrated bull. Anim. Behaviour. 14, 572-573.

Gassner, F.X.; Hill, H.J. and Sulzberger, L. (1952): Relationship of seminal fructose to testis function in the domestic animals Fert. Steril. 3, 121-143.

Humphrey, G.F. and Mann, T. (1949); Studies on the metabolism of semen. 5. Citric acid in semen. Biochem. J. 44, 97-105.

Lindner, H.R. and Mann, T. (1960): Relationship between the content of androgenic steroids in the testes and the secretory activity of the seminal vesicles in the bull. J. Endocrin. 21, 341-361.

Mann, T. (1948): Frutose content and fructolysis in semen. Practical application in the evaluation of semen quality. 1. Agric. Sci. 38, 323-331.

Mann, T. (1964): The Biochemistry of Semen of the Male Reproductive Tract. Mathuen and Co. Ltd. London.

Mann, T. and Parsons, U. (1950): Studies on the metabolism of semen 6- Role of hormones, effect of castration, hypophysectomy and diabetes. Relation between blood glucose and seminal fructose. Biochem. J. 46, 440-450.

Menn, T. Davies, D.V. and Humphrey, G.F. (1949): Fructase and citric acid assay in the secretions of the accessory glands of reproduction as indicator tests of male sex hormone activity. J. Endocrinol. 675.

Assiut Vet. Med. I. Vol. 12, No. 23, 1984. 


\section{CASTRATION \& REPRODUCTIVE ACTIVITY OF BUFFALO}

Osman, A.M. (1972): Studies on extragonadol reserves of spermatozoa (Vasa deferentia and ampullae) in water buffalo bulls. Zbl. Vet. Med. A., 19, 705-709.

Price , D. and Williams - Ashman, H.G. (1961): The accessory reproductive glands of mammals. In Sex and Internal secretions. Vol. 1, 3rd Ed. Young, W.C. (Editor). The Williams \& Wilkins Co., Baltimore.

Saffran, M. and Denstedt, O.F. (1948): A rapid method for the determination of citric acid. J. Biol. Chem. 175. 849.

Weisgold, A.D. and Almquist. J.O. (1979): Reproductive capacity of beef bulls. VI-Daily spermatozoal production, spermatozoal reserves, and dimensions and weight of reproductive organs. J. Anim. Sci. 48, 351-358.

\section{LEST OF FIGURES}

Fig. (1): Seminal vericle of buffalo bull 7 weeks after castration showing reduced alveoli size and deficiency in secretory material. $H$ \& E. ( $X 200)$.

Fig. (2): Seminal vesicle of buffalo bull 7 weeks after castration, showing normal size alveoli but with scanty secretion. Note the absence of basal vacuoles and bleb-like projections. $H$ \& E. ( $X$ 312.5).

Fig. (3): Prostate gland of castrated buffalo bull showing a decrease in aceni size and a deficiency in sectetory material. Note the increase in interstitial tissue. $H$ \& $E$. (X 200).

Fig. (4): Ampulla of castrated buffalo bull. Note the presence of inspissated materials in the ampullary glands. $H \& E$. (X 312.5). 
M.S.S. ABDOU, et al.

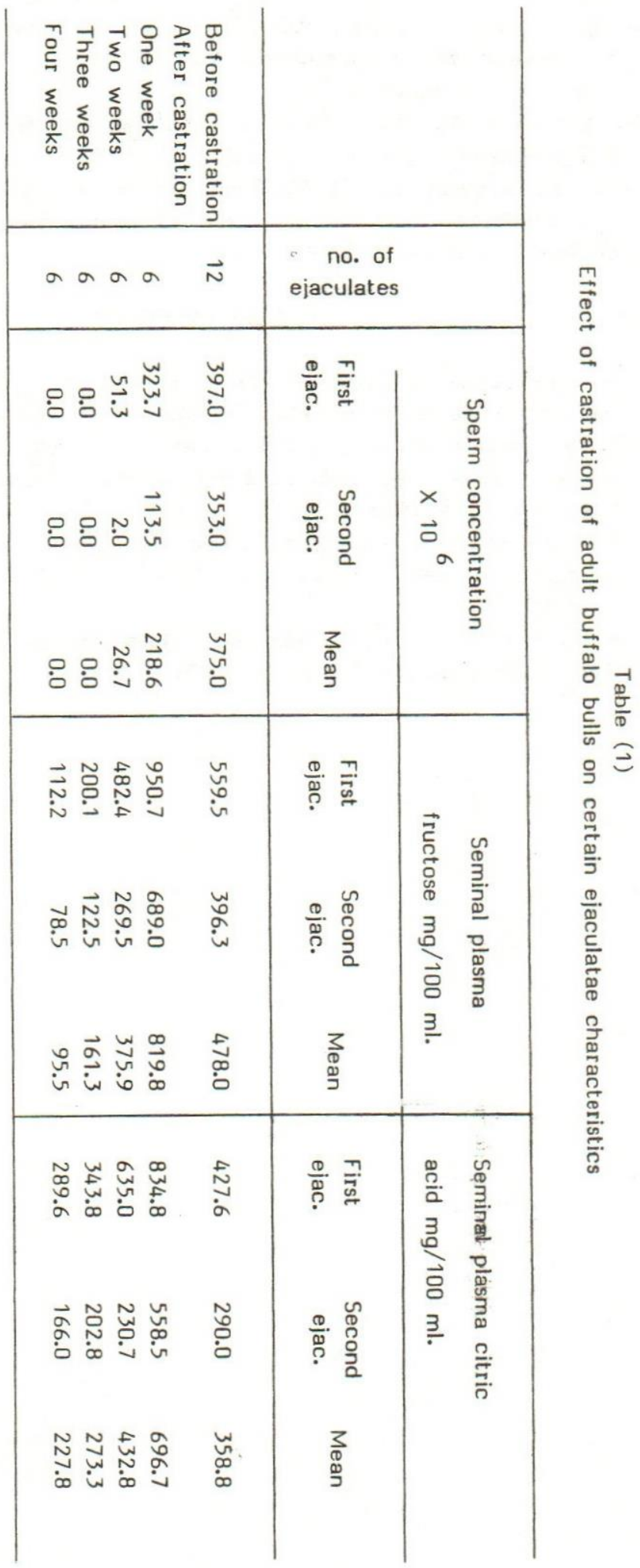


CASTRATION \& REPRODUCTIVE ACTIVITY OF BUFFALO

Table (2)

Average dimensions, weights fructose and citric acid concentration in the accessory glands of buffalo bulls 7 weeks after castration

\begin{tabular}{lcccc}
\hline \multicolumn{1}{c}{ Parameters } & $\begin{array}{c}\text { Vesicular } \\
\text { glands }\end{array}$ & Ampullae & $\begin{array}{c}\text { Internal } \\
\text { prostate }\end{array}$ & $\begin{array}{c}\text { Bulls } \\
\text { wiethrals }\end{array}$ \\
\hline Length (Cm.) & 5.8 & 12.8 & 6.8 & 3.5 \\
Width (Cm.) & 1.1 & - & 3.7 & 1.6 \\
Thickness (Cm.) & 0.9 & - & 3.3 & - \\
Diameter (Cm.) & - & 3.6 & 6.3 & - \\
Paired Weight & 16.2 & 3.9 & - & 5.6 \\
Fructose mg/100 g. & 29.7 & 31.6 & - & - \\
Citric acid mg/100 g. & & & & - \\
\hline
\end{tabular}




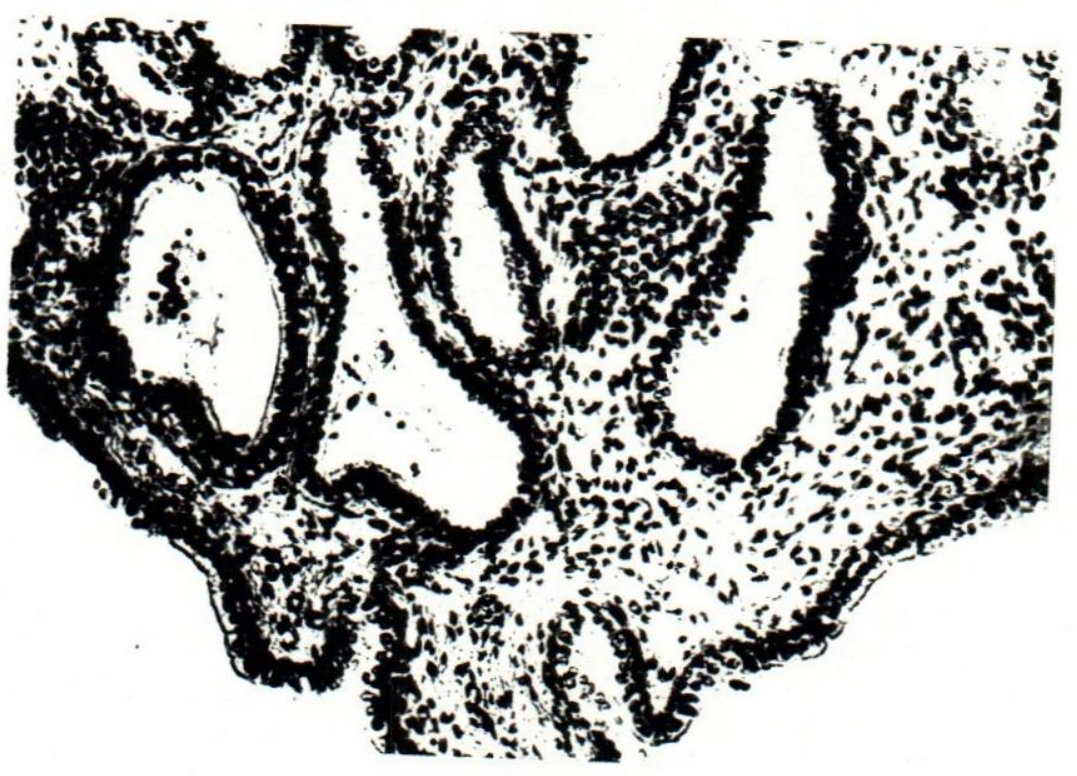

Fig. (1)

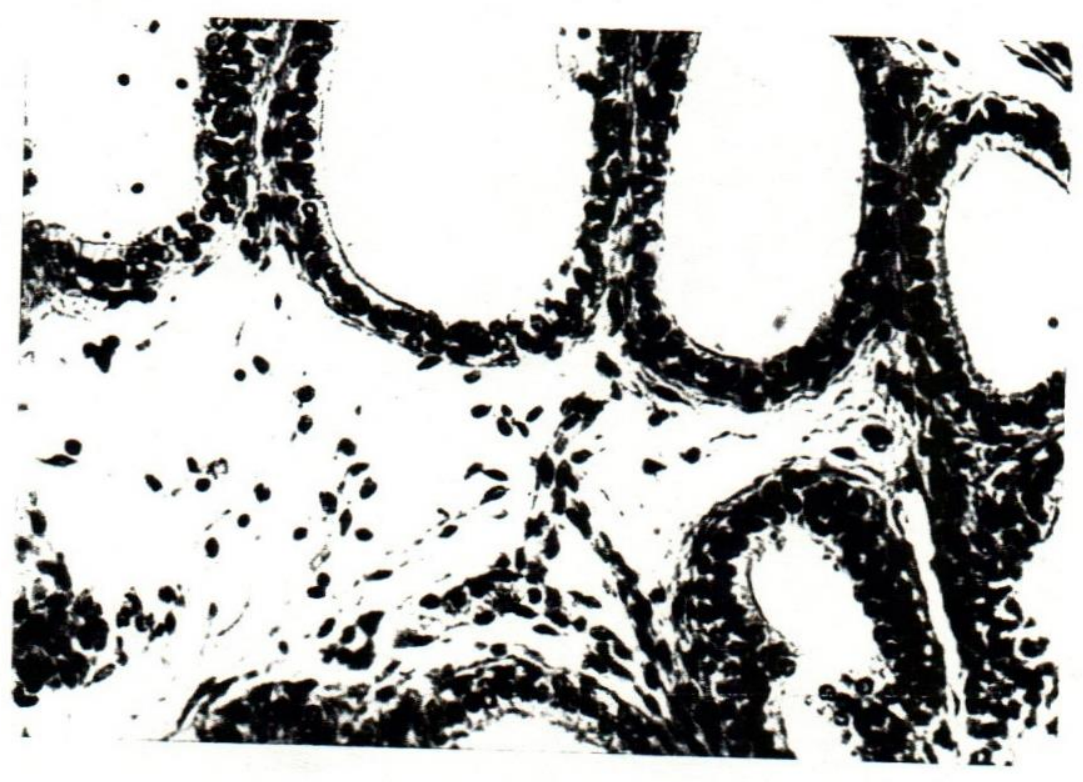

Fig. (2) 



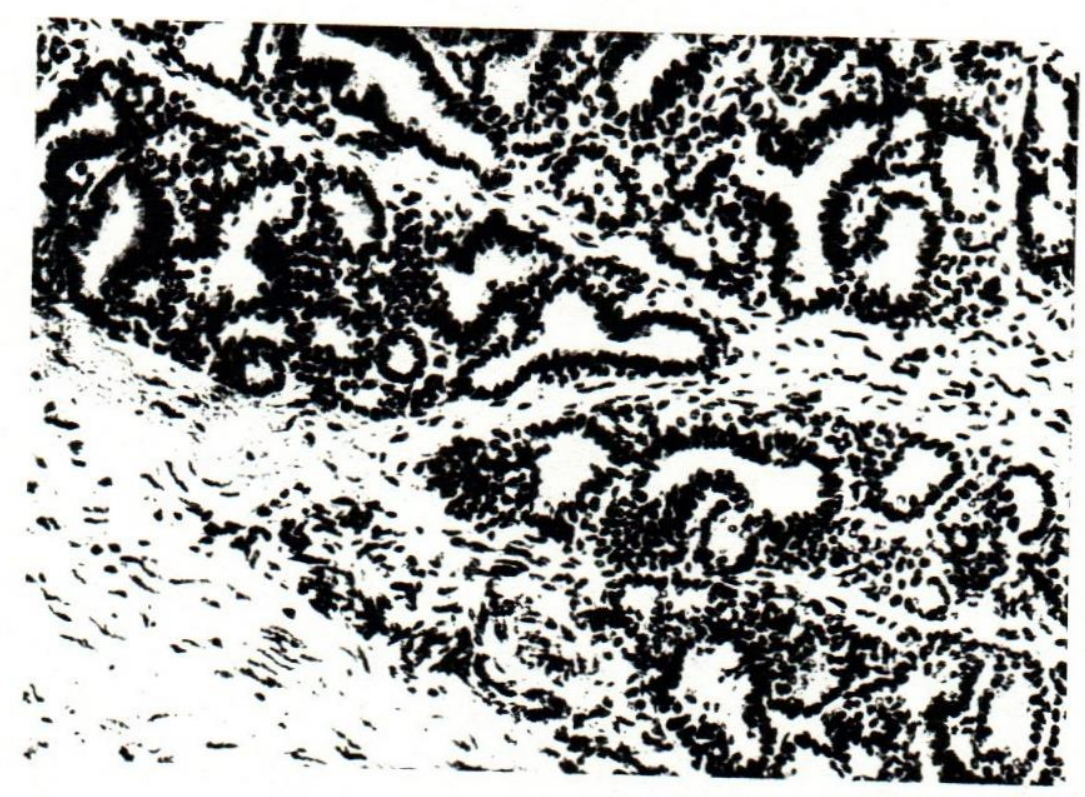

Fig. (3)

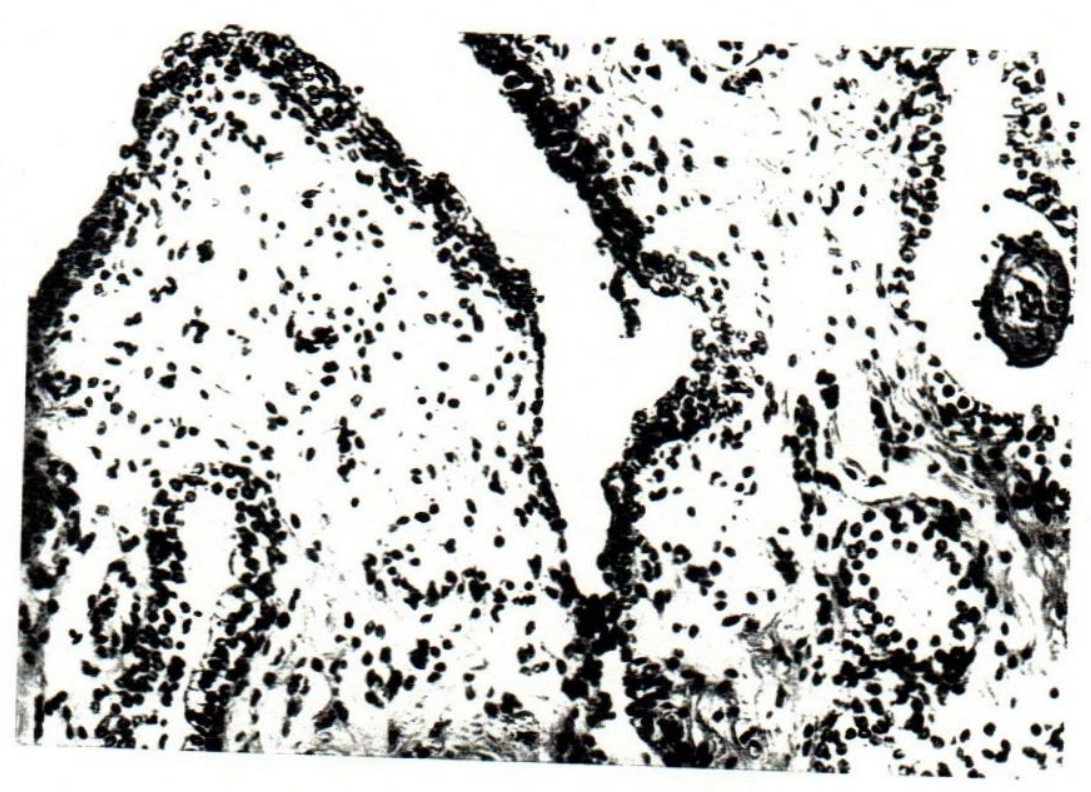

Fig. (4) 
